\title{
The Influence of Product Quality, Price, and Service Quality in Customer Loyalty at PT. Cybernetic Makmur Lestari
}

\author{
Arie Pratania Putri ${ }^{1}$, Alexander Wongkar ${ }^{2}$, Michael $^{3}$, Muhammad Rizki Balliansa ${ }^{4}$ \\ 1,2,3,4 Universitas Prima Indonesia
}

\begin{abstract}
The aims of this study is to fin out the Influence of Product Quality, Price, and Service Quality in Customer Loyalty at PT. Cybernetic Makmur Lestari. This study used qualitative method. The partial test results product quality variable (XI) has a positive and significant effect on consumer loyalty $(Y)$ at PT. Cybernetic Makmur Lestari.The partial test results variable price $(X 2)$ has a positive and significant effect on consumer loyalty $(Y)$ at PT. Cybernetic Makmur Lestari. The partial test results service quality variable (X3) has a positive and significant effect on consumer loyalty $(Y)$ at PT. Cybernetic Makmur Lestari. The simultaneous test results of variable product quality (X1) price (X2) and service quality (X3) simultaneously have a positive and significant effect on consumer loyalty at PT. Cybernetic Makmur Lestari amounted to $55.7 \%$ and the remaining $44.3 \%$ varied by other factors that were not researched such as location, personal selling, and physical evidence.
\end{abstract}

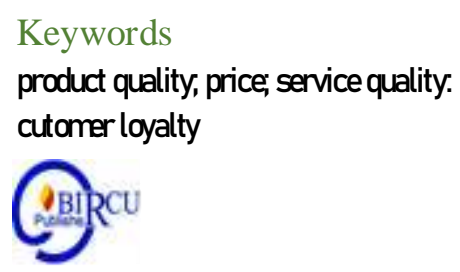

Keywords cutomer loyalty

\section{Introduction}

At the present time, companies that are established, whatever their form and nature, whether they are engaged in trade, industry or services, will try to achieve the stated goals. Of course, achieving this goal is not easy, because there are so many levels of competition that exist. Especially at a time when technological developments and advances in the industrial sector are very rapid, of course there are various obstacles that must be faced. In this case, the management must manage the existing resources in the company in order to function effectively and efficiently.

PT. Cybernetic Makmur Lestari is a company engaged in the sale of oil palm machine spare parts. Throughout 2018 the sales of PT. Cybernetic Makmur Lestari has experienced a decline and has not been able to achieve the sales target that has been set.

Sales of oil palm machine spare parts for PT. Cybernetic Makmur Lestari has not reached its sales target. The lowest sales occurred in January 2018 with the achievement of $69.9 \%$ of the target and the highest sales occurred in May 2018 with the achievement of sales of $96.7 \%$. Product quality is not in accordance with consumer desires, this has led to many consumer complaints about the quality of the product.

Beside the poor product quality, the selling price of oil palm machine spare parts at PT. Cybernetic Makmur Lestari is considered to be slightly more expensive than other companies, such as 6 inch screw conveyors selling for 9.3 million, while Indocentral only sells screw conveyors for 8.7. Apart from the high price of spare parts, consumers are also disappointed with the services provided by PT. Cybernetic Makmur Lestari.

Based on the problems that occur in the company, the researchers are interested in conducting research in this company, entitled "The Effect of Product Quality, Price, and Service Quality on Customer Loyalty at PT. Cybernetic Makmur Lestari". 


\section{Review of Literatures}

\subsection{The Theory of the Influence of Product Quality on Consumer Loyalty}

The development of business organizations depends on the quality of the products they produce. The better the product produced and useful, the more consumers will enjoy it, especially to meet their daily needs. The quality of products that are in great demand by consumers can be seen from several factors including packaging, price, quality, and benefits obtained by consumers. (Romdonny, 2019).

According to Abdullah and Tantri (2012: 26) "The concept of product insight argues that consumers will choose products that offer quality, best performance, or other innovative things".

According to Abdullah and Tantri (2012: 159) "Here, product quality means the product's ability to carry out its function. Including:

1. Durability

2. Reliability

3. Stipulation

4. Ease of use and repair

5. As well as other valuable attributes"

\subsection{The Theory of the Effect of Price on Consumer Loyalty}

Consumer behavior is very dynamic and tends to be adaptive, quickly adjust to the demand of the people who always need the public transport. Their demand is complex so that the government should create a good strategy for transport service quality. They need to be managed by the best managers in order to adapt to the users' expectation. In addition, a continuous performance valuation should also be done in order to narrow the gap between the expected and perceived service users. They should know the consumer behavior well, with a full understanding of the public habits. They even have to understand the people's movement and activities well. By doing so, the needs of consumers can be fulfilled. (Sukesi, 2018).

According to Hasan (2013: 521), price affects financial performance and has an important influence on buyer perception and brand placement.

According to Tjiptono (2016: 242), states that the role of price in marketing is very crucial. Price affects the level of demand, profitability, and consumer perceptions.

According to Kotler and Keller (2013: 76), companies must consider many factors in determining their pricing policies. The price indicators in this study consist of a six-step procedure, namely:

1. Choose a pricing destination

2. Determine the request

3. Estimating costs

4. Analyze costs, prices and competitors' offers

5. Choose a pricing method

6. Choose a final price

\subsection{Theory of Service Quality Influence on Consumer Loyalty}

According to Sangadji and Sopiah (2013: 98), because services have a high quality of experience and trust, the buyers will have more risks. This has several consequences. First, service consumers generally rely on word of mouth rather than advertising. Second, they are relying heavily on price, officers, and physical instructions to judge its quality. Third, they 
are very loyal to service providers who satisfy them. Service firms face three tasks, namely increasing competitive differentiation, quality and service, and productivity.

Service quality can be defined as "The extent of discrepancy between customers' expectations or desires and their perceptions". From this statement stated the difference between the expectations or desires of consumers with their level of perception Zeithaml in Fortunata (2020).

According to Lupiyoadi (2013: 212) in determining the level of satisfaction, a customer often sees the added value of a service performance received from a service purchase process. The value added by a service to the customer is the answer to the question of why a customer makes his choice. Customers are basically looking for the greatest value a service provides.

According to Parasuraman in Sangadji and Sopiah (2013: 100-101), the dimensions of quality are:

1. Reliability

Namely the ability to deliver the promised services accurately and dependably, especially to provide services in a timely manner (on time), in the same way according to the promised schedule, and without making mistakes;

2. Responsiveness

Namely the willingness or desire of employees to help provide services that consumers need;

3. Assurance

Includes knowledge, ability, friendliness, politeness and trustworthiness of personal contact to eliminate the indecisive nature of consumers and make them feel free from harm and risk;

4. Empathy

Which includes the attitude of personal or company contacts to understand the needs and difficulties, consumers, good communication, personal attention, and ease of communication or relationships;

5. Physical products

The availability of physical facilities, equipment and means of communication, etc. that can and must be in the service process.

\subsection{Conceptual Framework}

Based on the formulation of the problem and the literature review that has been described previously regarding the variable price and product quality and their effect on purchasing decisions, it can be concluded as follows:

Product quality is the ability of a product to carry out its function. Because with a high selling price of a product, consumers will expect the quality of a product to be the best possible. The more it can last for a long time, the more positive the product will be in the eyes of consumers.

Price is a very important part for buyers and sellers. For buyers, price is a consideration in the purchasing decision-making process. For sellers, the pricing is based on the expected profit that will be obtained in the future. Through a price agreement, a product, the exchange of products and services will only occur. Price is also a determining factor in reaching a purchase decision.

Service quality is an important part. Service quality is all actions or performance that the company can offer to customers which are essentially intangible and do not generate any ownership but the benefits can be felt by the customer. Because with the quality of service, buyers will get their own satisfaction. Then the conceptual framework proposed in this study is described as follows 


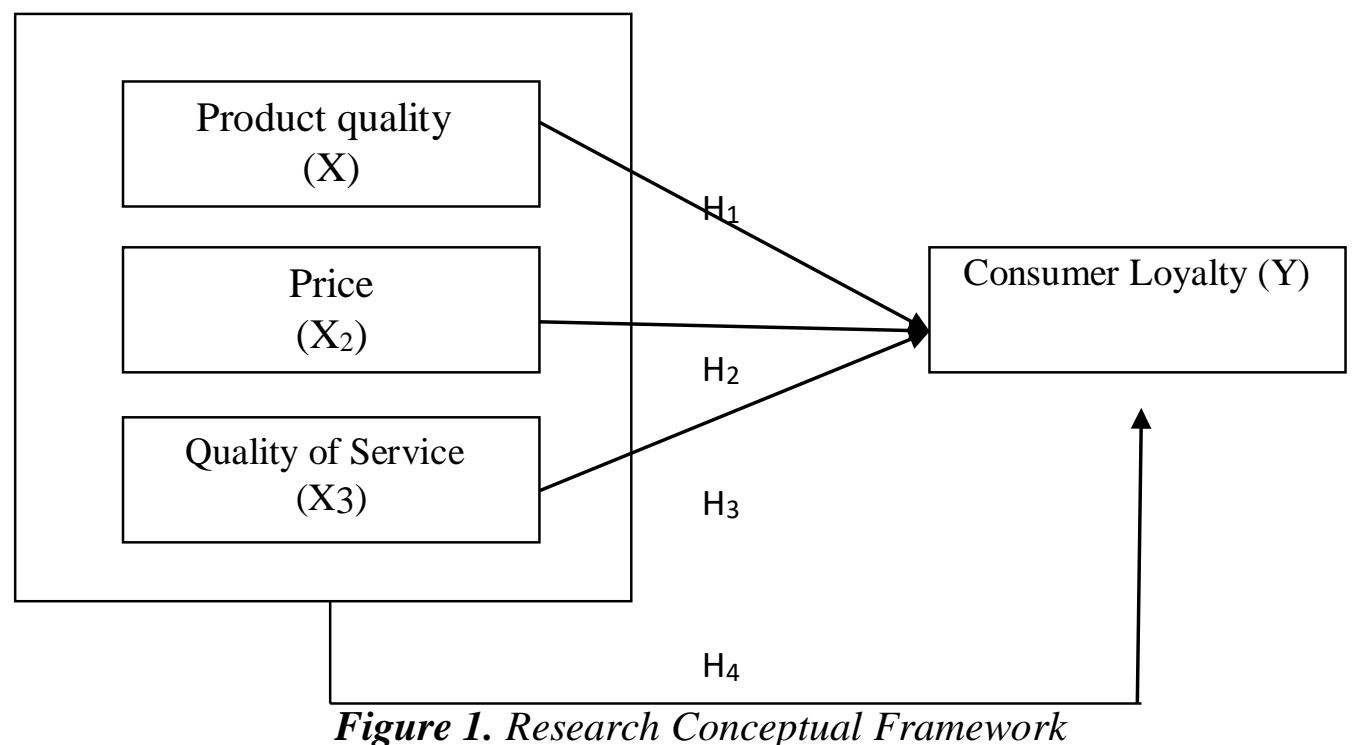

III. Research Method

\subsection{Research Methods}

According to Sanusi (2011: 28), the research method is the whole process of thinking from starting to find, selecting and formulating research problems, reviewing literature, collecting data, analyzing data, and interpreting the results to drawing conclusions.

\subsection{Population and Sample}

The population used in this study were all consumers at PT. Cybernetic Makmur Lestari in 2019 totaled 137 people.

The sample technique used in the study was saturated sampling. According to Sugiyono (2011: 85), "saturated sampling is a sampling technique when all members of the population are the sample" Then the number of samples used by the researcher was 137 consumers of PT. Cybernetic Makmur Lestari.

\subsection{Identification and Operational Definition of Research Variables}

The operational definitions for each dependent variable and independent variable are as follows:

Table 1. Identification and Operational Definition of Research Variables

\begin{tabular}{|l|l|l|c|}
\hline $\begin{array}{l}\text { Research } \\
\text { Variable }\end{array}$ & \multicolumn{1}{|c|}{ Definition } & \multicolumn{1}{|c|}{ Indicator } & \multicolumn{1}{c|}{$\begin{array}{c}\text { Measurement } \\
\text { Scale }\end{array}$} \\
\hline Product \\
quality (X1) & Product quality is the product's & 1. Durability & \\
& $\begin{array}{l}\text { ability to carry out its functions } \\
\text { including durability, reliability, }\end{array}$ & $\begin{array}{l}\text { 2. Reliability } \\
\text { 3. Stipulation }\end{array}$ & \multirow{2}{*}{ Likert } \\
& $\begin{array}{l}\text { accuracy, ease of use, repair, and } \\
\text { other valuable attributes. }\end{array}$ & $\begin{array}{l}\text { 4. Ease of use and repair } \\
\text { 5. As well as other valuable } \\
\text { attributes ". }\end{array}$ & \\
& Abdullah dan Tantri (2012:159) & Abdullah dan Tantri & \\
& & & \\
& & & \\
\hline
\end{tabular}




\begin{tabular}{|c|c|c|c|}
\hline $\begin{array}{l}\text { Price } \\
\text { (X2) }\end{array}$ & $\begin{array}{l}\text { Price is all forms of monetary } \\
\text { costs that are sacrificed by } \\
\text { consumers to obtain, having taken } \\
\text { advantage of a number of } \\
\text { combinations of goods and } \\
\text { services from a product. } \\
\text { Hasan (2013:521) }\end{array}$ & $\begin{array}{l}\text { 1. Cost of goods } \\
\text { 2. Discount } \\
\text { 3. Payment method }\end{array}$ & Likert \\
\hline $\begin{array}{l}\text { Quality of } \\
\text { Service } \\
\text { (X3) }\end{array}$ & $\begin{array}{l}\text { Quality is a dynamic condition } \\
\text { related to products, services, } \\
\text { people, processes and the } \\
\text { environment that meet or } \\
\text { exceed expectations } \\
\text { Sangadji \& Sopiah (2013:99) }\end{array}$ & $\begin{array}{l}\text { 1. Reliability (reliability) } \\
\text { 2. Responsiveness } \\
\text { (responsiveness) } \\
\text { 3. Assurance (assurance) } \\
\text { 4. Empathy } \\
\text { 5. Physical products } \\
\text { (tangibles) } \\
\text { Sangadji \& Sopiah } \\
\text { (2013:100- 101) }\end{array}$ & Likert \\
\hline $\begin{array}{l}\text { Consumer } \\
\text { Loyalty } \\
\text { (Y) }\end{array}$ & $\begin{array}{l}\text { Customer (consumer) loyalty is } \\
\text { a customer's commitment to a } \\
\text { store or supplier brand, based } \\
\text { on a very positive attitude and } \\
\text { is reflected in consistent repeat } \\
\text { purchases. } \\
\text { Sangadji \& Sopiah (2013:104) }\end{array}$ & $\begin{array}{l}\text { 1. Make repeat purchases } \\
\text { regularly } \\
\text { 2. Make purchases outside } \\
\text { the product line } \\
\text { 3. Recommend products } \\
\text { 4. Demonstrate immunity } \\
\text { from the attraction of } \\
\text { similar products from } \\
\text { competitors } \\
\text { Jill Griffin (Dalam } \\
\text { Hurriyati, 2010:130) }\end{array}$ & Likert \\
\hline
\end{tabular}

\subsection{Test the Validity and Reliability of Variable Instruments}

\section{a. Validity Test}

According to Ghozali (2011: 52), the validity test is used to measure whether a questionnaire is valid or not. A questionnaire is said to be valid if the questions on the questionnaire are able to reveal something that will be measured by the questionnaire. In this study, the sample used for the validity test was 30 people.

\section{b. Reliability Test}

According to Ghozali (2011: 47), the definition of reliability is a measuring tool for measuring a questionnaire which is an indicator of a variable or construct. A questionnaire is said to be reliable or reliable if someone's answer to a question is consistent or stable over time.

\subsection{Classic Assumption Test}

\section{a. Normality Test}

According to Ghozali (2011: 160), the normality test aims to test whether in the regression model, confounding or residual variables have a normal distribution. There are two ways to detect whether the residuals are normally distributed or not, namely by graph analysis and statistical tests.

\section{b. Multicollinearity Test}

According to Ghozali (2011: 105), the multicollinearity test aims to test whether the regression model found a correlation between independent (independent) variables. 


\section{c. Heteroscedasticity Test}

According to Ghozali (2011: 139), the heteroscedasticity test aims to test whether in the regression model there is an inequality of variance from the residuals of one observation to a constant observation, it is called Homoscedasticity and if it is different it is called heteroscedasticity.

\subsection{Research Data Analysis Model}

a. Research Model

According to Sanusi (2011: 135) the multiple regression model equation is as follows:

$$
\mathbf{Y}=\mathbf{a}+\mathbf{b}_{1} \mathbf{X}_{1}+\mathbf{b}_{2} \mathbf{X}_{2}+\mathbf{b}_{3} \mathbf{X}_{3}+\mathbf{e}
$$

\section{b. Hypothesis Determination Coefficient $\left(\mathbf{R}^{2}\right)$}

According to Gujarati (2003 in Ghozali (2011: 97), if the empirical test results in a negative adjusted $\mathrm{R}^{2}$ value, then the adjusted $\mathrm{R}^{2}$ value is considered to be zero. Mathematically, if the value of $R^{2}=1$ then adjusted $R 2=R^{2}=1$, whereas if the value of $R^{2}=$ 0 , then adjusted $R^{2}=(1-k) /(n-k)$. If $k>1$, then adjusted $R^{2}$ will be negative.

\section{c. Hypothesis Determination Coefficient $\left(\mathbf{R}^{3}\right)$}

The simultaneous testing criteria (F test) are as follows:

$\mathrm{H} 0: \mathrm{b} 1, \mathrm{~b} 2, \mathrm{~b} 3=0$ (product quality, price and service quality simultaneously have no effect on consumer loyalty at PT. Cybernetic Makmur Lestari)

$\mathrm{H} 1: \mathrm{b} 1, \mathrm{~b} 2, \mathrm{~b} 3 \neq 0$ (product quality, price and service quality simultaneously affect consumer loyalty at PT. Cybernetic Makmur Lestari)

\section{d. Partial Hypothesis testing (t test)}

The simultaneous testing criteria ( $\mathrm{t}$ test) are as follows:

$\mathrm{H} 0: \mathrm{b} 1=\mathrm{b} 2=\mathrm{b} 3=0$ (product quality; price; service quality simultaneously has no effect on consumer loyalty at PT. Cybernetic Makmur Lestari)

$\mathrm{H} 1: \mathrm{b} 1=\mathrm{b} 2=\mathrm{b} 3 \neq 0$ (product quality; price; service quality simultaneously affects customer loyalty at PT. Cybernetic Makmur Lestari)

\section{Result and Discussion}

\subsection{Overview of PT. Cybernetic Makmur Lestari}

PT. Cybernetic Makmur Lestari is a company with experience in supplying spare parts and plantation equipment for the palm oil mill industry. We supply units and parts for boilers, digesters, haul roads, etc. PT. Cybernetic Makmur Lestari is a group of Sdn Bhd's first palm oil mill in Malaysia. Therefore, this company is one of the most comprehensive suppliers in Indonesia.

PT. Cybernetic Makmur Lestari was founded in 2007 and is located in Medan, North Sumatra, Indonesia. The company has experience in palm oil mills for more than 10 years. Back then, we were just a small company. Over time, our company is slowly growing due to customer satisfaction with our products. As a result, it makes us able to compete with other big companies and even companies on the same level as our company as our competitors. All the products we supply are imported from abroad, especially from Malaysia, Singapore, several European countries and the US.

Our company motto is product quality and service is our priority. Quality is the only solution to prevent damage during processing time. We will be happy to serve you. 


\subsection{Descriptive statistics}

Descriptive analysis is used to describe the summary of research data such as mean, minimum, maximum, standard deviation, variance, mode and others. In this case the users of descriptive statistics cannot draw generalized conclusions (generalizations), because the statistics here are limited to existing things only. The results of the analysis here are still simple, in fact most (most) of the analysis or calculations are simplification of the data collected. Descriptive statistics can be seen in the following table:

\begin{tabular}{|l|r|r|r|r|r|}
\multicolumn{7}{|c}{ Table 2. Descriptive Statistics } \\
& N & Minimum & Maximum & Mean & Std. Deviation \\
\hline Product quality & 137 & 12.00 & 38.00 & 27.7737 & 8.01835 \\
Price & 137 & 9.00 & 30.00 & 21.6204 & 6.25221 \\
Quality_Service & 137 & 9.00 & 30.00 & 21.5255 & 5.89252 \\
Customer_Loyalty & 137 & 8.00 & 30.00 & 21.0438 & 6.68720 \\
Valid N (listwise) & 137 & & & & \\
\hline
\end{tabular}

Based on Table 2, it can be seen the data description of product quality, price, service quality and consumer loyalty. The variable product quality with a sample of 137 respondents has an average of 27.7737 units with a minimum product quality of 12 units is the 103th respondent's answer and a maximum of 38 units is the answer of the 5,21,120 respondents, and 132 with a standard deviation of 8,01835 units.

The price variable of 137 respondents has an average of 21.6204 units with a minimum price of 9 units is the 73rd respondent's answer and a maximum of 30 units is the answer of the 6th and 96th respondents with a standard deviation of 6.25221 units.

The service quality variable as many as 137 respondents had an average of 21.5255 units with a minimum service quality of 9 units which was the 73rd respondent's answer and a maximum of 30 units was the 94th respondent's answer with a standard deviation of 5.89252 units.

The consumer loyalty variable as many as 137 respondents has an average of 21.0438 units with a minimum purchase decision of 8 units which is the 73rd respondent's answer and a maximum of 30 units is the 94th respondent's answer with a standard deviation of 6,68720 units.

\subsection{Validity and Reliability Test}

Table 3. Results of the Validity Test of Product Quality Variables

\begin{tabular}{|c|l|c|c|c|}
\hline No & \multicolumn{1}{|c|}{ Question } & $\begin{array}{l}\text { Corrected } \\
\text { Item Total } \\
\text { Correlation }\end{array}$ & $\begin{array}{c}\text { Sig (2- } \\
\text { tailed) }\end{array}$ & Information \\
\hline 1 & $\begin{array}{l}\text { According to Mr / Ms, the products offered by PT. } \\
\text { Benua Teknik Abadi is not easy to damage and } \\
\text { durable? }\end{array}$ & 0.878 & 0.000 & Valid \\
\hline 2 & $\begin{array}{l}\text { According to Mr / Ms, the products offered by PT. } \\
\text { Benua Teknik Abadi could be used for a longer } \\
\text { period of time compared to competitors' products? }\end{array}$ & 0.793 & 0.000 & Valid \\
\hline 3 & $\begin{array}{l}\text { Please agree that the products offered by PT. Benua } \\
\text { Teknik Abadi according to customer expectations? }\end{array}$ & 0.672 & 0.000 & Valid \\
\hline 4 & $\begin{array}{l}\text { Please agree that the products offered PT. Benua } \\
\text { Teknik Abadi is always trusted by customers? }\end{array}$ & 0.857 & 0.000 & Valid \\
\hline
\end{tabular}




\begin{tabular}{|c|l|c|c|c|}
\hline 5 & $\begin{array}{l}\text { Please agree that the products offered PT. Benua } \\
\text { Teknik Abadi easy to install? }\end{array}$ & 0.928 & 0.000 & Valid \\
\hline 6 & $\begin{array}{l}\text { Please agree that the products of PT. Benua Teknik } \\
\text { Abadi is easy repaired in case of damage? }\end{array}$ & 0.758 & 0.000 & Valid \\
\hline 7 & $\begin{array}{l}\text { Please agree that the products offered by PT. Benua } \\
\text { Teknik Abadi is a quality item? }\end{array}$ & 0.730 & 0.000 & Valid \\
\hline 8 & $\begin{array}{l}\text { Please agree that the products offered by PT. Benua } \\
\text { Teknik Abadi has the SNI standard? }\end{array}$ & 0.893 & 0.000 & Valid \\
\hline
\end{tabular}

Based on table 3 above, it shows that the results of testing the product quality variable instrument have a value of $r_{\text {count }} \geq r_{\text {table }}(0.3610)$. Thus it can be concluded that all question instruments regarding the variable quality of the product are valid so that they can be used in research. This conclusion is reinforced by the significance value (2-tailed) of all instruments which is smaller than $\alpha$ by $5 \%$.

Table 4. Results of the Price Variable Validity Test

\begin{tabular}{|c|l|c|c|c|}
\hline No & \multicolumn{1}{|c|}{ Question } & $\begin{array}{l}\text { Corrected } \\
\text { Item Total } \\
\text { Correlation }\end{array}$ & $\begin{array}{l}\text { Sig (2- } \\
\text { tailed) }\end{array}$ & Information \\
\hline 1 & $\begin{array}{l}\text { Please agree Mr / Ms, that the product price } \\
\text { offered by PT. Benua Teknik Abadi Technique is } \\
\text { cheap? }\end{array}$ & 0.922 & 0.000 & Valid \\
\hline 2 & $\begin{array}{l}\text { Please agree Mr / Ms, that the product price } \\
\text { offered by PT. Benua Teknik Abadi is comparable } \\
\text { to its product quality? }\end{array}$ & 0.927 & 0.000 & Valid \\
\hline 3 & $\begin{array}{l}\text { Agreed Mr / Ms, that PT. Benua Teknik Abadi } \\
\text { always delivers discounts to customers? }\end{array}$ & 0.602 & 0.000 & Valid \\
\hline 4 & $\begin{array}{l}\text { According to Mr / Ms, PT. Benua Teknik Abadi } \\
\text { provides discounts to customers more often than its } \\
\text { competitors? }\end{array}$ & 0.766 & 0.000 & Valid \\
\hline 5 & $\begin{array}{l}\text { According to Mr / Ms, PT. Benua Teknik Abadi } \\
\text { had variations payments such as debit cards, credit } \\
\text { cards and transfers? }\end{array}$ & 0.917 & 0.000 & Valid \\
\hline 6 & $\begin{array}{l}\text { Agreed Mr / Ms, that alternative payment methods } \\
\text { are offered PT. Benua Teknik Abadi makes it } \\
\text { easy for customers? }\end{array}$ & 0.837 & 0.000 & Valid \\
\hline
\end{tabular}

Based on table 4 above, it shows that the results of testing the price variable instrument have a value of rhitung $\geq$ rtabel (0.3610). Thus it can be concluded that all question instruments regarding price variables are valid so that they can be used in research. This conclusion is reinforced by the significance value (2-tailed) of all instruments which is smaller than $\alpha$ by $5 \%$.

Table 5. Test Results of the Validity of Service Quality Variables

\begin{tabular}{|c|l|c|c|c|}
\hline No & \multicolumn{1}{|c|}{ Question } & $\begin{array}{l}\text { Corrected } \\
\text { Item Total } \\
\text { Correlation }\end{array}$ & $\begin{array}{l}\text { Sig (2- } \\
\text { tailed) }\end{array}$ & Information \\
\hline 1 & $\begin{array}{l}\text { According to Mr / Ms, that Sales PT. Benua } \\
\text { Teknik Abadi was always on-time in visiting } \\
\text { customers? }\end{array}$ & 0.889 & 0.000 & Valid \\
\hline 2 & According to Mr / Ms, that PT. Benua Teknik & 0.780 & 0.000 & Valid \\
\hline
\end{tabular}




\begin{tabular}{|c|c|c|c|c|}
\hline & $\begin{array}{l}\text { Abadi has always been keep promises in terms of } \\
\text { delivery schedule? }\end{array}$ & & & \\
\hline 3 & $\begin{array}{l}\text { According to Mr / Ms, that the employees of PT. } \\
\text { Benua Teknik Abadi was always responsive and } \\
\text { empathetic in dealing with the problems at hand } \\
\text { customer? }\end{array}$ & 0.651 & 0.000 & Valid \\
\hline 4 & $\begin{array}{l}\text { According to Mr / Ms, that the sales of PT. Benua } \\
\text { Teknik Abadi has always been responsive in } \\
\text { receiving every complaint from customers? }\end{array}$ & 0.922 & 0.000 & Valid \\
\hline 5 & $\begin{array}{l}\text { According to Mr / Ms, that the sales of PT. Benua } \\
\text { Teknik Abadi was capable provide solutions to } \\
\text { problems faced by customers? }\end{array}$ & 0.921 & 0.000 & Valid \\
\hline 6 & $\begin{array}{l}\text { According to Mr / Ms, that the sales of PT. Benua } \\
\text { Teknik Abadi was always able to provide logical } \\
\text { answers in case of late delivery } \\
\text { goods? }\end{array}$ & 0.590 & 0.000 & Valid \\
\hline 7 & $\begin{array}{l}\text { According to Mr / Ms, that the sales of PT. Benua } \\
\text { Teknik Abadi has always been honest in notifying } \\
\text { the schedule of delivery of goods to customers? }\end{array}$ & 0.846 & 0.000 & Valid \\
\hline 8 & $\begin{array}{l}\text { According to Mr / Ms, that PT. Benua Teknik } \\
\text { Abadi can the customers trust? }\end{array}$ & 0.826 & 0.000 & Valid \\
\hline
\end{tabular}

Based on table 5 above, it shows that the results of testing the service quality variable instrument have a value of rhitung $\geq$ rtabel (0.3610). Thus it can be concluded that all question instruments regarding service quality variables are valid so that they can be used in research.

This conclusion is strengthened by the significance value (2-tailed) of all instruments which is smaller than $\alpha$ by $5 \%$.

Table 6. Results of the Validity Test of Consumer Loyalty Variables

\begin{tabular}{|c|l|c|c|c|}
\hline No & \multicolumn{1}{|c|}{ Question } & $\begin{array}{l}\text { Corrected } \\
\text { Item Total } \\
\text { Correlation }\end{array}$ & $\begin{array}{c}\text { Sig (2- } \\
\text { tailed) }\end{array}$ & Information \\
\hline 1 & $\begin{array}{l}\text { According to Mr / Ms, who always buy products } \\
\text { through PT. Immortal Technique Continent? }\end{array}$ & 0.948 & 0.000 & Valid \\
\hline 2 & $\begin{array}{l}\text { According to Mr / Ms, who always buy products } \\
\text { through PT. } \\
\text { Immortal Technique Continent? }\end{array}$ & 0.980 & 0.000 & Valid \\
\hline 3 & $\begin{array}{l}\text { According to Mr / Ms, who recommend PT. } \\
\text { Continent } \\
\text { Immortal Technique to others? }\end{array}$ & 0.497 & 0.005 & Valid \\
\hline 4 & $\begin{array}{l}\text { According to Mr / Ms, who always say positive } \\
\text { things about PT. Continent of Immortal Technique } \\
\text { to others? }\end{array}$ & 0.915 & 0.000 & Valid \\
\hline 5 & $\begin{array}{l}\text { According to Mr / Ms, who always place PT. } \\
\text { Continent of Engineering } \\
\text { Abadi as the main choice in buying palm oil } \\
\text { machine spare parts? }\end{array}$ & 0.882 & 0.000 & Valid \\
\hline 6 & $\begin{array}{l}\text { According to Mr / Ms, who want to subscribe to } \\
\text { PT. Immortal Technique Continent and would } \\
\text { never consider the company other? }\end{array}$ & 0.909 & 0.000 & Valid \\
\hline
\end{tabular}


Based on table 6 above, it shows that the results of testing the customer satisfaction variable instrument have a value of rhitung $\geq$ rtabel (0.3610). Thus it can be concluded that all question instruments about the variable consumer loyalty are valid so that they can be used in research. This conclusion is reinforced by the significance value (2-tailed) of all instruments which is smaller than $\alpha$ by $5 \%$.

Table 7 Variable Instrument Reliability Test Results

\begin{tabular}{|c|c|c|c|}
\hline Variable & Cronbcah Alpha & Number of Items & Information \\
\hline Product quality & 0,925 & 8 & Reliable \\
\hline Price & 0,911 & 6 & Reliable \\
\hline Quality of Service & 0,928 & 8 & Reliable \\
\hline $\begin{array}{c}\text { Consumer } \\
\text { Loyalty }\end{array}$ & 0,935 & 6 & Reliable \\
\hline
\end{tabular}

\subsection{Classic Assumptions}

a. Normality Test

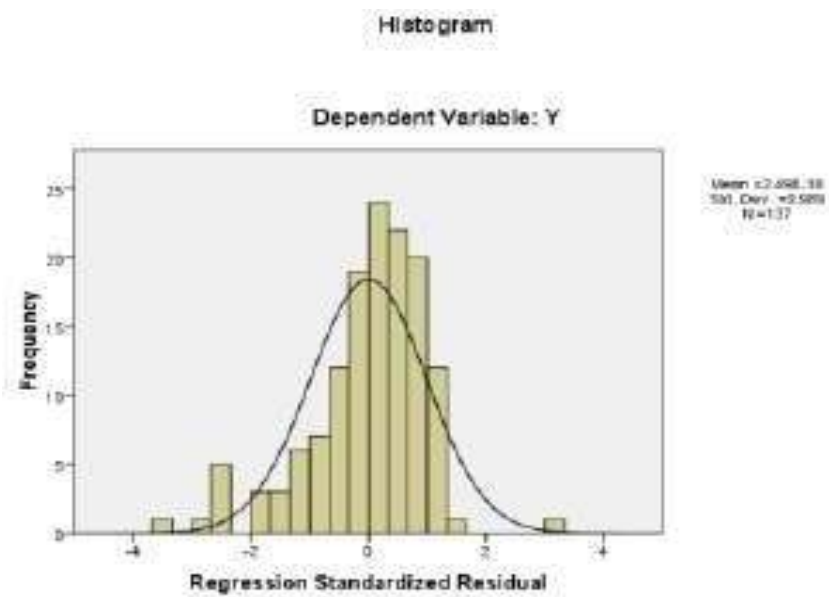

Figure 2. Histogram Graph

Based on Figure 2, it can be seen that the line drawing is in the form of a bell, not turning left or right. This shows that the data is normally distributed and meets the assumptions of normality.

Normal P-P Plot of Regression Standardized

Residual

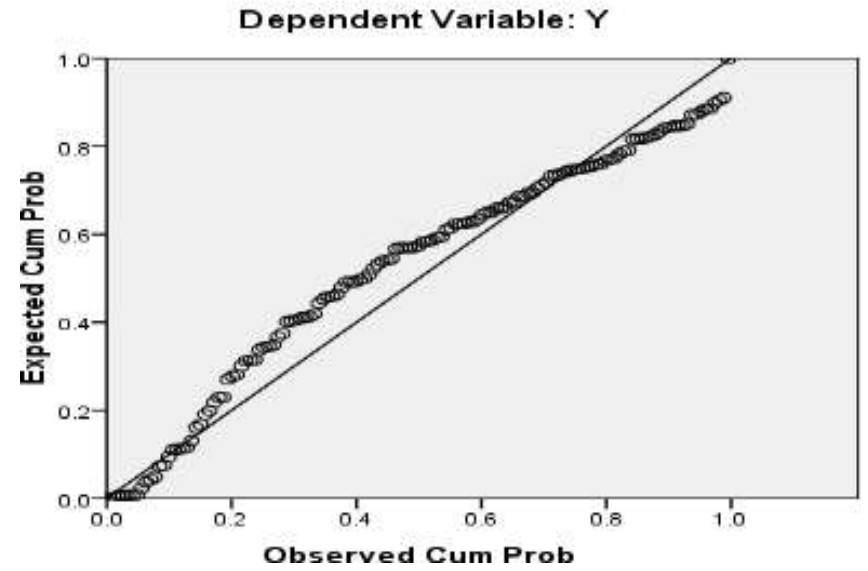

Figure 3. Results of Normal P-Plot Graph Testing 
Figure 3 shows that the data (dots) spread around the diagonal line and follow the diagonal line. So, Figure IV.3 can be concluded that the residuals in the regression model are normally distributed.

Table 8. The Results of Normality Testing of One Sample Kolmogorov-Smirnov Test

\begin{tabular}{|ll|r|}
\hline & & \multicolumn{1}{|c|}{$\begin{array}{c}\text { Unstandardized } \\
\text { Residual }\end{array}$} \\
\hline $\mathrm{N}$ & & 137 \\
Normal Parameters a,,b & Mean & .0000000 \\
& Std. Deviation & 4.35568215 \\
Most Extreme & Absolute & .108 \\
Differences & Positive & .084 \\
& Negative & -.108 \\
Kolmogorov-Smirnov Z & & 1.263 \\
Asymp. Sig. (2-tailed) & & .052 \\
\hline
\end{tabular}

a. Test distribution is Normal.

b. Calculated from data.

Source: Results of primary data processing (questionnaire, SPSS)

Based on the output results in table 8, the value (Asym. Sig 2-tailed) is obtained of 0.052 because the significance is greater than $5 \%(0.05)$, so the residuals are normally distributed.

\subsection{Multicollinearity Test}

Table 9. Multicollinearity Test Results

\begin{tabular}{|ll|r|c|}
\hline \multicolumn{2}{|c|}{ Coefficients $^{\mathbf{a}}$} \\
\cline { 3 - 4 } Model & & \multicolumn{2}{|c|}{ Collinearity Statistics } \\
\cline { 2 - 4 } & & Tolerance & VIF \\
\hline 1 & (Constant) & & \\
& Product quality & .465 & 2.151 \\
& Price & .463 & 2.161 \\
& Quality_Service & .373 & 2.682 \\
\hline
\end{tabular}

a. Dependent Variable: Customer_Loyalty

Source: Results of primary data processing (questionnaire, SPSS)

Based on Table 9, it is known that the two independent variables, namely product quality, have a VIF of less than 10 , namely 2.151 , while the tolerance value is above 0.1 , which is 0.465 , the price variable has a VIF of less than 10 , namely 2.161 , while the tolerance value is above 0.1 , namely 0.463 and the service quality variable has a VIF of less than 10 , which is 2.682, while the tolerance value is above 0.1 , which is 0.373 . Thus, it can be concluded that the regression equation is free from multicollinearity assumptions. 


\subsection{Heteroscedasticity Test}

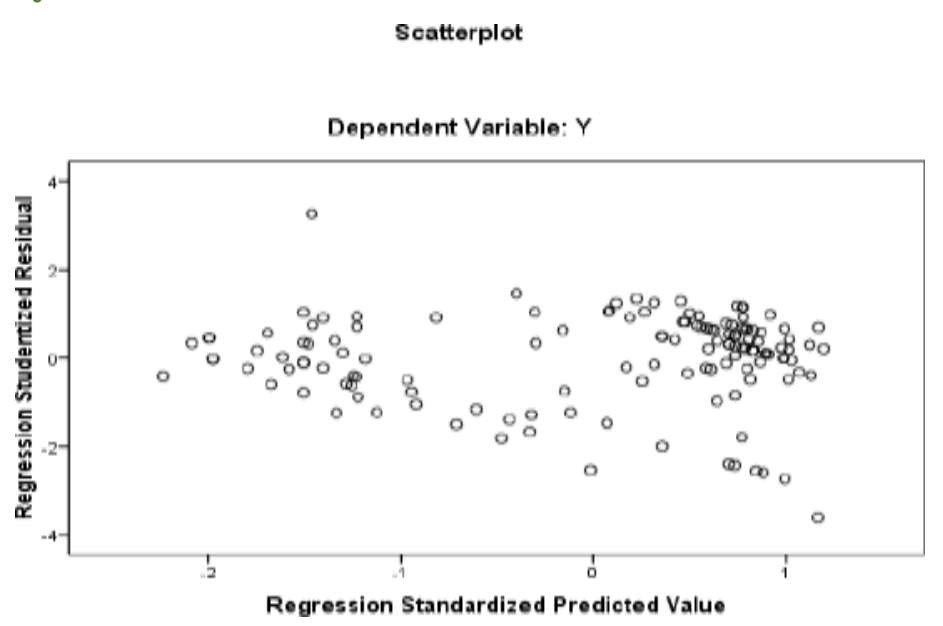

Figure 4. Heteroscedasticity Test Results

Source: Results of primary data processing (questionnaire, SPSS)

From the results of Figure 4 above, it can be seen that the dots are scattered randomly (randomly) and are spread above or below the number 0 on the $\mathrm{Y}$ axis, so it can be concluded that there is no heteroscedasticity problem in the regression model so the regression model is feasible to use.

Table 10. Glejser Heteroscedaticity Test Results

Coefficients $\mathbf{a}^{\mathrm{a}}$

\begin{tabular}{|c|c|c|c|c|c|}
\hline \multirow[b]{2}{*}{ Model } & \multicolumn{2}{|c|}{ Unstandardized Coefficients } & \multirow{2}{*}{\begin{tabular}{|c|}
$\begin{array}{c}\text { Standardized } \\
\text { Coefficients }\end{array}$ \\
Beta \\
\end{tabular}} & \multirow[b]{2}{*}{$\mathrm{t}$} & \multirow[b]{2}{*}{ Sig. } \\
\hline & $\mathrm{B}$ & Std. Error & & & \\
\hline 1 (Constant) & 2.370 & 1.038 & & 2.284 & .02 \\
\hline Product quality & .003 & .046 & .008 & .064 & .9 \\
\hline Price & .058 & .060 & .123 & .967 & .33 \\
\hline Quality_Service & -.020 & .070 & -.041 & -.288 & .774 \\
\hline
\end{tabular}

a. Dependent Variable: ABSUT

Source: Results of primary data processing (questionnaire, SPSS)

From table 10 it can be seen that the probability value (sig.) For the product quality variable is 0.949 , the price variable is 0.335 and the service quality variable is 0.774 . So, it can be concluded that the regression model does not contain heteroscedasticity because the significance value is above $5 \%(0.05)$.

\subsection{Results of Data Analysis}

Analysis of research data used in this study is a multiple regression analysis model. This analysis model is used to determine the independent variable on the dependent variable either jointly or partially. The results of the calculation output from the SPSS program are as follows 
Table 11. Multiple Regression Analysis Test Results

\begin{tabular}{|c|c|c|c|c|c|}
\hline \multirow[b]{2}{*}{ Model } & \multicolumn{2}{|c|}{ Unstandardized Coefficients } & \multirow{2}{*}{\begin{tabular}{|c|}
$\begin{array}{c}\text { Standardized } \\
\text { Coefficients }\end{array}$ \\
Beta
\end{tabular}} & \multirow[b]{2}{*}{$\mathrm{t}$} & \multirow[b]{2}{*}{ Sig. } \\
\hline & B & Std. Error & & & \\
\hline $\begin{array}{ll}1 & \text { (Constant) } \\
& \text { Product quality } \\
& \text { Price } \\
& \text { Quality_Service }\end{array}$ & $\begin{array}{r}1.157 \\
.140 \\
.275 \\
.467\end{array}$ & $\begin{array}{r}1.562 \\
.070 \\
.090 \\
.106\end{array}$ & $\begin{array}{l}.168 \\
.257 \\
.411\end{array}$ & $\begin{array}{r}.741 \\
2.011 \\
3.058 \\
4.402\end{array}$ & $\begin{array}{l}.460 \\
.046 \\
.003 \\
.000\end{array}$ \\
\hline
\end{tabular}

a. Dependent Variable: Y

Source: Results of primary data processing (questionnaire, SPSS)

From table 11, the multiple regression equation can be formulated as follows:

Consumer Loyalty $=1.157+0.140$ (Product Quality) - 0.275 (Price) +0.467 (Service Quality)

From the results of the regression equation above, it can be explained as follows:

a. Kosntanta $(\alpha)=1.157$ means that although the independent variable $\left(X_{1}\right)$ is the product quality of the independent variable $\left(\mathrm{X}_{2}\right)$, namely the price and the independent variable $\mathrm{X}_{2}$, namely the quality of service is 0 , then customer loyalty (Y) at PT. Cybernetic Makmur Lestari is fixed at 1,157 units.

b. The coefficient of $\mathrm{X}_{1}(\mathrm{~b} 1)=0.140$ and is positive. The variable of product quality on consumer loyalty with a regression coefficient of 0.140 units. This means that every time there is an increase in the customer satisfaction variable by 1 unit, then the customer satisfaction of PT. Cybernetic Makmur Lestari will increase by 0.140 units.

c. The coefficient of $\mathrm{X}_{2}(\mathrm{~b} 2)=0.275$ and is positive. Price variable towards consumer loyalty with a regression coefficient of 0.275 units. This means that every time there is an increase in the price variable by 1 unit, then the consumer loyalty of PT. Cybernetic Makmur Lestari will decrease by 0.275 units.

d. The coefficient of $\mathrm{X}_{3}(\mathrm{~b} 3)=0.467$ and is positive. The variable of product quality on consumer loyalty with a regression coefficient of 0.467 units. This means that every time there is an increase in the product quality variable by 1 unit, then the consumer loyalty of PT. Cybernetic Makmur Lestari will increase by 0.467 units.

\subsection{Hypothesis Determination Coefficient Test Results $\left(\mathbf{R}^{2}\right)$}

Table 12. Hypothesis Determination Coefficient

Model Summaryb

\begin{tabular}{|l|r|r|r|c|}
\hline Model & R & R Square & $\begin{array}{l}\text { Adjusted R } \\
\text { Square }\end{array}$ & $\begin{array}{l}\text { Std. Error of } \\
\text { the Estimate }\end{array}$ \\
\hline 1 & .753 & .567 & .557 & $\begin{array}{l}4.4507 \\
1\end{array}$ \\
\hline
\end{tabular}

a. Predictors: (Constant), a. Quality_Service, Price, Product_ Quality

b. Dependent Variable: Customer_Loyalty

Source: Results of primary data processing (questionnaire, SPSS)

Table 12 shows the Adjusted R Square value of 0.557 , which means that $55.7 \%$ can be explained by the influence of product quality, price and service quality on consumer loyalty of PT. Cybernetic Makmur Lestari and the remaining 44.3\% were varied by other variables that were not studied such as location, personal selling and physical evidence. 


\subsection{Simultaneous Hypothesis Testing Results (Test F)}

Table 13. F test

ANOVA ${ }^{b}$

\begin{tabular}{|ll|r|r|r|r|c|}
\hline \multicolumn{1}{|l|}{ Model } & Sum of Squares & \multicolumn{1}{c|}{ df } & Mean Square & F & \multicolumn{1}{c|}{ Sig. } \\
\hline 1 & Regression & 3447.166 & 3 & 1149.055 & 58.00 & .000 \\
& & & & 7 & $\mathrm{a}$ \\
& Residual & 2634.571 & 133 & 19.809 & & \\
Total & 6081.737 & 136 & & & \\
\hline
\end{tabular}

a. Predictors: (Constant), X3, X1, X2

b. Dependent Variable: Y

Source: Results of primary data processing (questionnaire, SPSS)

According to Sanusi (2011: 138) the F distribution table is searched by looking at the degrees of freedom one $(\mathrm{df} 1)=$ number of variables $-1=4-1=3$ and by looking at the two degrees of freedom $(\mathrm{df} 2)=\mathrm{n}-\mathrm{k}-1$ or $137-4-1=132$ ( $\mathrm{n}$ is the amount of data and $\mathrm{k}$ is the number of variables) so that the value for the $\mathrm{F}$ table is 2.67 .

Based on table 13, it can be seen that the value of Fcount> Ftable $(58.007>2.67)$ and the significance of $0.000<0.05$. This indicates that the research results reject $\mathrm{H} 0$ and accept H1. Thus product quality, price and service quality have a positive and significant effect on consumer loyalty at PT. Cybernetic Makmur Lestari.

\subsection{Result of Partial Hypothesis testing (t test)}

Table 14. $t$ test

\section{Coefficient}

a

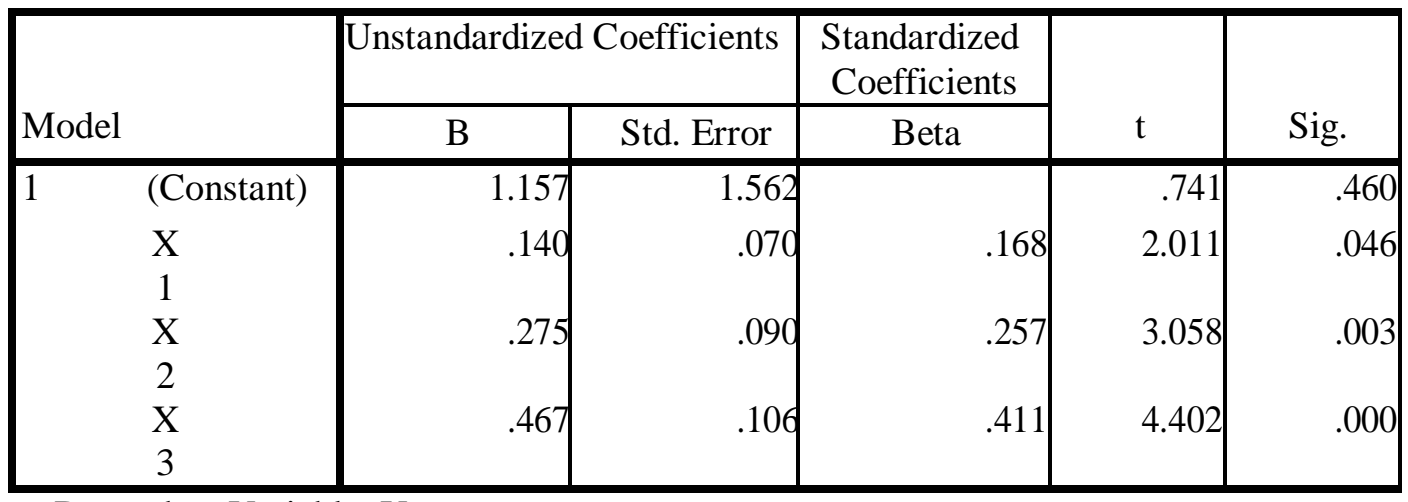

a. Dependent Variable: Y

Source: Results of primary data processing (questionnaire, SPSS)

According to Sanusi $(2011: 138)$ the $t$ distribution table is sought at $\alpha=5 \%: 2=2.5 \%$ (two-sided test) with degrees of freedom $(\mathrm{df})=\mathrm{n}-\mathrm{k}-1$ or $137-4-1=132(\mathrm{n}$ is the number of data and $\mathrm{k}$ is the number of variables). With a two-sided test (significance $=0.025$ ) the results obtained for $\mathrm{t}$ table are 1.97810 .

Based on table 14, the following results are obtained:

1. Result of Partial Hypothesis Test of Product Quality Variables

From table 12, it can be seen that the value of $\mathrm{t}$ count is compared with $\mathrm{t}$ table so that the variable product quality $\left(\mathrm{X}_{1}\right)$ is $2.011>1.97810$ and the significanceof $0.046(0.046$ $<0.05$ ). So in the research results reject $\mathrm{H} 0$ and accept $\mathrm{H} 1$, meaning that product quality has a positive and significant effect on consumer loyalty at PT. Cybernetic Makmur 
Lestari. Every buyer certainly expects a durable and long lasting product. Therefore, the products produced by PT. Cybernetic Makmur Lestari is expected to be able to fulfill the desires and expectations of consumers (durable and long lasting) so that consumer loyalty can be created.

2. The Results of the Price Variable Partial Hypothesis Test

From table 12, it can be seen that the value of t count is compared to the value of t table so that the variable price (X2) is 3.058> 1.97810 and the significance is $0.003(0.003<0.05)$. So in the research results reject $\mathrm{H} 0$ and accept $\mathrm{H} 1$, meaning that price has a positive and significant effect on consumer loyalty at PT. Cybernetic Makmur Lestari. Thus it can be concluded that price is a sacrifice required by consumers to obtain a product or service. Through a price agreement, the exchange of products and services will occur. Therefore, the price felt by consumers is appropriate for a product or service, it will create consumer loyalty.

3. Results of the Service Quality Variable Partial Hypothesis Test

From table 12, it can be seen that the value of $t$ count is compared to the value of $t$ table so that the variable service quality $\left(\mathrm{X}_{3}\right)$ is $4.402>1.97810$ and the significance is 0.000 $(0.000<0.05)$. So in the research results reject $\mathrm{H} 0$ and accept $\mathrm{H} 1$, meaning that service quality has a positive and significant effect on consumer loyalty at PT. Cybernetic Makmur Lestari. Good quality service will certainly give a good impression in the hearts of customers so that customers will feel comfortable transacting with the company concerned. Therefore, the quality of service is very important to be evaluated regularly so that the company can provide better service.

\section{Conclussion}

The conclusions of this study are as follows:

1. The partial test results product quality variable $\left(X_{1}\right)$ has a positive and significant effect on consumer loyalty (Y) at PT. Cybernetic Makmur Lestari.

6. The partial test results variable price $\left(\mathrm{X}_{2}\right)$ has a positive and significant effect on consumer loyalty (Y) at PT. Cybernetic Makmur Lestari.

7. The partial test results service quality variable $\left(\mathrm{X}_{3}\right)$ has a positive and significant effect on consumer loyalty (Y) at PT. Cybernetic Makmur Lestari.

8. The simultaneous test results of variable product quality $\left(\mathrm{X}_{1}\right)$ price $\left(\mathrm{X}_{2}\right)$ and service quality $\left(\mathrm{X}_{3}\right)$ simultaneously have a positive and significant effect on consumer loyalty at PT. Cybernetic Makmur Lestari amounted to 55.7\% and the remaining $44.3 \%$ varied by other factors that were not researched such as location, personal selling, and physical evidence.

\section{Suggestion}

The suggestions that the author can give to companies based on the results of this study are as follows:

1. For product quality problems, PT. Cybernetic Makmur Lestari must continue to make improvements in terms of product quality by implementing check quality control on each product so that customer satisfaction can be properly fulfilled.

2. For price issues, PT. Cybernetic Makmur Lestari should consider pricing more in order to be able to compete in the market to increase company sales and improve employee performance to create consumer loyalty. 
3. For service quality problems, PT. Cybernetic Makmur Lestari must improve employee service to consumers by conducting regular training so that the services provided to consumers can continue to improve.

4. PT. Cybernetic Makmur Lestari must pay attention to product quality, price, and service quality issues in order to create consumer loyalty to the company. It is hoped that PT. Cybernetic Makmur Lestari did several things suggested by researchers in order to achieve company goals.

\section{References}

Abdullah \& Tantri. (2013). Manajemen Pemasaran. Depok: Raja Grafindo Persada.

Abdullah, M.Rizan. (2016). Pengaruh Harga dan Kualitas Pelayanan Terhadap Loyalitas Pelanggan pada PT. Alakasa Extrusindo. Jurnal Manajerial, Volume 9 No.2

Ghozali, Imam. (2011). Aplikasi Analisis Multivariate dengan Program IBM SPSS 19. Ed. V, Semarang: Universitas Diponegoro.

Fortunata, R. and Toni, N. (2020). The Influence of Service Quality, Tuition Fee and Promotion on Student Decisions to Continue Study in Postgraduate of Prima Indonesia University. Budapest International Research and Critics Institute-Journal (BIRCIJournal). P. 829-837

Hasan, Ali. (2013). Marketing dan Kasus-Kasus Pilihan. Cetakan Pertama. Yogyakarta: CAPS. Herviana, Anik. 2018. Pengaruh Kualitas Produk dan Harga Terhadap Loyalitas dengan Kepuasan Sebagai Variabel Intervening (Studi pada Konsumen Biskuit Oreo di Carefour Surabaya).Jurnal Ilmu Manajemen, Volume 6 No.1

Philip Kotler \& Kevin Lane Keller. (2013). Manajemen Pemasaran. Edisi 13. Jilid2. Jakarta.Erlangga.

Rambat Lupiyoadi, A.Hamdani.(2013). Manajemen Pemasaran Jasa. Edisi 2. Jakarta. Salemba Empat.

Romdonny, J. et al. (2019). Factors Affecting Customer Loyalty in Products. Budapest International Research and Critics Institute-Journal (BIRCI-Journal). P. 337-343

Sangadji, Etta Mamang \& Sopiah.(2013). Perilaku Konsumen. Ed. 1, Yogyakarta: CV. Andi Offset.

Sanusi, Anwar, (2011). Metodologi Penelitian Bisnis. Cetakan Keempat. Jakarta: Salemba Empat.

Shandy, et al. (2014). Pengaruh Kualitas Layanan dan Kualitas Produk terhadap Kepuasan Pelanggan dan Loyalitas Konsumen Restoran Happy Garden Surabaya. Jurnal Manajemen Pemasaran, Volume 2 No.1

Sugiyono, (2012). Metodologi Penelitian Bisnis. Cetakan Keenam belas. Bandung: Alfabeta. Tjiptono, Fandy. 2012. Service Management : Mewujudkan Layanan Prima. Edisi Kedua. Yogyakarta : Penerbit Andi.

Sukesi, and Yunus, E. (2018). Service Quality in Public Transport Services of the Provicial Intercity Transportation (AKDP) in East Java Indonesia. Budapest International Research and Critics Institute-Journal (BIRCI-Journal). P. 161-169 